\title{
Receptor Interacting Protein Kinase-Mediated Necrosis Contributes to Cone and Rod Photoreceptor Degeneration in the Retina Lacking Interphotoreceptor Retinoid-Binding Protein
}

\author{
Kota Sato, ${ }^{1}$ Songhua Li, ${ }^{1}$ William C. Gordon, ${ }^{1}$ Jibao He, ${ }^{2}$ Gregory I. Liou, ${ }^{3}$ James M. Hill, ${ }^{1}$ Gabriel H. Travis, ${ }^{4}$ \\ Nicolas G. Bazan, ${ }^{1}$ and Minghao Jin ${ }^{1}$ \\ ${ }^{1}$ Department of Ophthalmology and Neuroscience Center of Excellence, Louisiana State University Health Sciences Center, New Orleans, Louisiana 70112, \\ 2Electron Microscope Laboratory, Tulane University, New Orleans, Louisiana 70118, ${ }^{3}$ Department of Ophthalmology, Georgia Health Sciences University, \\ Augusta, Georgia 30912, and ${ }^{4}$ Jules Stein Eye Institute, The University of California, Los Angeles School of Medicine, Los Angeles, California 90095
}

Interphotoreceptor retinoid-binding protein (IRBP) secreted by photoreceptors plays a pivotal role in photoreceptor survival with an unknown mechanism. A mutation in the human $I R B P$ has been linked to retinitis pigmentosa, a progressive retinal degenerative disease. Mice lacking IRBP display severe early and progressive photoreceptor degeneration. However, the signaling pathway(s) leading to photoreceptor death in IRBP-deficient mice remains poorly understood. Here, we show that amounts of tumor necrosis factor- $\alpha$ (TNF- $\alpha$ ) in the interphotoreceptor matrix and retinas of $\operatorname{Irbp}{ }^{-1-}$ mice were increased more than 10-fold and fivefold, respectively, compared with those in wild-type mice. Moreover, TNF- $\alpha$ receptor 1 , an important membrane death receptor that mediates both programmed apoptosis and necrosis, was also significantly increased in $\operatorname{Irbp} p^{-1-}$ retina, and was colocalized with peanut agglutinin to the Irbp ${ }^{-1-}$ cone outer segments. Although these death signaling proteins were increased, the caspase-dependent and independent apoptotic pathways were mildly activated in the $\operatorname{Irbp} p^{-1-}$ retinas, suggesting that other cell death mechanism(s) also contributes to the extensive photoreceptor degeneration in Irbp ${ }^{-1-}$ retina. We found that receptor interacting protein 1 and 3 (RIP1 and RIP3) kinases, the intracellular key mediators of TNF-induced cellular necrosis, were elevated at least threefold in the Irbp ${ }^{-1-}$ retinas. Moreover, pharmacological inhibition of RIP1 kinase significantly prevented cone and rod photoreceptor degeneration in Irbp ${ }^{-1-}$ mice. These results reveal that RIP kinase-mediated necrosis strongly contributes to cone and rod degeneration in $I r b p^{-1-}$ mice, implicating the TNF-RIP pathway as a potential therapeutic target to prevent or delay photoreceptor degeneration in patients with retinitis pigmentosa caused by IRBP mutation.

\section{Introduction}

Interphotoreceptor retinoid-binding protein (IRBP) is an interphotoreceptor matrix (IPM) glycolipoprotein (Liou et al., 1982; Bazan et al., 1985; Fong and Bridges, 1988; Borst et al., 1989) secreted by photoreceptors (Gonzalez-Fernandez et al., 1984; van Veen et al., 1986). Its well known function is to bind with 11-cisretinal, 11-cis- and all-trans retinols in IPM (Bridges et al., 1984; Crouch et al., 1992). IRBP promotes release of 11-cis retinal from the retinal pigment epithelium (RPE; Carlson and Bok, 1992) and all-trans retinoid from the neural retina (Qtaishat et al., 2005; Wu

Received March 26, 2013; revised Sept. 15, 2013; accepted Sept. 29, 2013.

Author contributions: K.S., S.L., and M.J. designed research; K.S., S.L., W.C.G., J. He, and M.J. performed research; G.I.L., J. Hill, G.H.T., and N.G.B. contributed unpublished reagents/analytic tools; K.S., S.L., and M.J. analyzed data; K.S., S.L., and M.J. wrote the paper.

This work was supported by NIH Grant EY021208 (M.J.) and departmental grants from RPB and the Lions Eye Foundation. We thank Mr. Ryan Labadens for his editorial assistance.

The authors declare no competing financial interests.

Correspondence should be addressed to Minghao Jin at the above address. E-mail: mjin@|suhsc.edu.

DOI:10.1523/JNEUROSCI.1380-13.2013

Copyright $\odot 2013$ the authors $\quad 0270-6474 / 13 / 3317458-11 \$ 15.00 / 0$ et al., 2007; Jin et al., 2009) and is involved in the rod and cone visual cycles (Jin et al., 2009; Parker et al., 2009; Parker et al., 2011). Since IRBP is expressed in the early embryonic stage, it may participate in the retinal development (Eisenfeld et al., 1985; Carter-Dawson et al., 1986; Gonzalez-Fernandez and Healy, 1990; Liou et al., 1994). Recently, a mutation that causes a secretory defect has been found in the IRBP gene of patients with retinitis pigmentosa (den Hollander et al., 2009; Li et al., 2013b), a frequent cause of retinal degeneration. Mice lacking IRBP display rod and cone degeneration (Liou et al., 1998; Ripps et al., 2000; Jin et al., 2009; Wisard et al., 2011). The molecular and cellular mechanisms leading to photoreceptor degeneration in $\operatorname{Irbp} \mathrm{p}^{-1-}$ mice and patients with the IRBP mutation remain largely unknown.

Apoptosis has been shown to be involved in photoreceptor degeneration in $I r b p^{-1-}$ mice. Wisard et al. (2011) observed a spike in TUNEL-positive cell counts ( $\sim 15$ cells/retinal section $)$ in the $I r b p^{-1-}$ outer nuclear layer at postnatal day 25 (P25). The counts of TUNEL-positive photoreceptors are significantly reduced after P25 (Wisard et al., 2011), whereas photoreceptor 
degeneration continues after P25 in Irbp ${ }^{-1-}$ mice (Ripps et al., 2000; Wisard et al., 2011). These observations suggest that apoptosis may contribute to a small portion of $I r b p^{-1-}$ photoreceptor death in a short time period, and that an alternative cell death pathway(s) is activated during the progressive photoreceptor degeneration in $I r b p^{-1-}$ retina.

Recent studies have shown that cellular necrosis contributes to cone and rod degeneration in animal models of retina degeneration (Trichonas et al., 2010; Murakami et al., 2012). Receptorinteracting protein 3 (RIP3) kinase, the key mediator of cellular necrosis induced by TNF- $\alpha$ (Cho et al., 2009; He et al., 2009; Zhang et al., 2009), is significantly elevated in retinas detached from RPE (Trichonas et al., 2010) and in the phase of cone degeneration in the $r d 10$ mouse model for retinitis pigmentosa (Murakami et al., 2012). RIP3 deficiency and inhibition of RIP1 kinase, another key player in cellular necrosis, significantly prevents cone and rod degeneration in these models of retina degeneration (Trichonas et al., 2010; Murakami et al., 2012).

In the present study, we investigated involvement of caspasedependent and -independent apoptosis, as well as RIP kinasemediated necrosis, in cone and rod degeneration in Irbp ${ }^{-1-}$ mice. We show that, in addition to apoptosis, RIP kinase-mediated necrosis strongly contributes to cone and rod degeneration in Irbp ${ }^{-1-}$ retina.

\section{Materials and Methods}

Animals. All animal experiments were performed in accordance with the Association for Research in Vision and Ophthalmology (ARVO) statement for the use of animals in ophthalmic and vision research, and were approved by the institutional animal care and use committee for the Louisiana State University Health Sciences Center, New Orleans, LA. Except where noted, mice were maintained in $12 \mathrm{~h}$ cyclic light at $\sim 30$ lux. The $129 \mathrm{~S} 2 / \mathrm{Sv}$ (Charles River Laboratories) and $\operatorname{Irbp}{ }^{-1-}$ mice are homozygous for the Leu450 allele in the Rpe65 gene. P14, 4- and 8 -week-old mice of either sex were used for the experiments unless otherwise specified.

Induction of photoreceptor apoptosis in mice. Acute photoreceptor degeneration in 129S2/Sv mice was induced by exposing animals to intense light for $9 \mathrm{~h}$ as described previously (Li et al., 2013a) or by injecting $1 \mu \mathrm{l}$ of $5 \mathrm{~mm}$ NMDA into the vitreous as described previously (Laabich and Cooper, 2000).

Treatment with Necrostatin-1, Nec-1 stable, and Nec-1 inactive. The Irbp ${ }^{-1-}$ mice at P12 were injected intraperitoneally with $45 \mu \mathrm{g}$ of Necrostatin-1 (Nec-1; 5-[(1 H-indol-3-yl)methyl]-3-methyl-2-thioxoimidazolidin-4-one, BioVision) or Nec-1 stable (Nec-1s; 5-[(7-Cl-1 H-indol-3-yl) methyl]-3-methylimidazolidine-2,4-dione, BioVision) per gram body weight every day for 2 or 6 weeks. Nec-1s is a RIP1-specific inhibitor, whereas Nec-1 can inhibit both RIP1 and indoleamine 2,3-dioxygenase (IDO; Takahashi et al., 2012; Degterev et al., 2013). Irbp ${ }^{-1-}$ mice injected with $20 \mu \mathrm{g}$ of Nec-1 inactive (Nec-1i; 5-[(1 H-indol-3-yl)methyl]-2-thioxoimidazolidin4-one, EMD Millipore) or vehicle [50\% dimethyl sulfoxide (DMSO) in saline] under the same conditions were used as controls. Nec-li can inhibit both RIP1 and IDO, but its inhibition of RIP1 is $100 \times$ less effective than $\mathrm{Nec}-1$ in vitro and is $10 \times$ less potent than Nec-1 and Nec-1s in the mouse necroptosis assay (Takahashi et al., 2012).

Cryosections. Enucleated mouse eyeballs were fixed overnight with $4 \%$ paraformaldehyde (PFA) in $0.1 \mathrm{~m}$ phosphate buffer (PB). After removing cornea and lens, eyecups were immersed in $15 \%$ sucrose in $0.1 \mathrm{M} \mathrm{PB}$ for $2 \mathrm{~h}$, in $30 \%$ sucrose in $0.1 \mathrm{M} \mathrm{PB}$ for $2 \mathrm{~h}$, and then in a 1:1 mixture of $30 \%$ sucrose and Optimal Cutting Temperature (OCT) medium (Sakura Finetechnical) overnight at $4^{\circ} \mathrm{C}$. After embedding eyecups in OCT, 10$\mu \mathrm{m}$-thick sections were cut on a Shandon Cryostom SME (Thermo Scientific). For double staining of RIP3 antibody and peanut agglutinin (PNA), enucleated eyeballs were immediately embedded into OCT and cryosections cut at $15 \mu \mathrm{m}$ thickness were fixed in cold acetone at $-20^{\circ} \mathrm{C}$ for $15 \mathrm{~min}$.
Table 1. Primary antibodies used

\begin{tabular}{lll}
\hline Primary antibody & Host & Company \\
\hline S-opsin & Goat & Santa Cruz Biotechnology \\
M-opsin & Rabbit & Millipore \\
$\alpha$-fodrin & Mouse & Enzo Life Science \\
Cleaved caspase-3 & Rabbit & Cell Signaling Biotechnology \\
m-calpain & Rabbit & Abcam \\
$\mu$-calpain & Mouse & Sigma-Aldrich \\
AlF & Rabbit & Abcam \\
TNF-receptor 1 & Rabbit & Abcam \\
RIP1 & Mouse & BD Bioscience \\
RIP3 & Rabbit & Sigma-Aldrich \\
$\beta$-tubulin & Rabbit & Sigma-Aldrich \\
\hline
\end{tabular}

Antibodies. Primary antibodies used in immunohistochemistry and immunoblot analysis are listed in Table 1 . The Alexa Fluor 488, 555, or 568 dye-conjugated anti-mouse or rabbit IgG antibodies (Invitrogen) and the horseradish peroxidase (HRP)-conjugated anti-rabbit antibody (PerkinElmer) were used as secondary antibodies.

Immunohistochemistry and PNA staining. After washing in $0.05 \%$ Tween 20 in PBS (Tw-PBS), cryosections were incubated in blocking buffer ( $1 \%$ skim milk in Tw-PBS), in primary antibody, and in secondary antibody as described previously (Sato et al., 2010). For the peptideblocking experiment, the anti-RIP3 antibody was neutralized with fivefold amount of the immunogenic peptide (AQFGRGRGWQPFHK, corresponding to amino acid residues 473-486 of mouse RIP3) before incubating with a cryosection. Fluorescent signal amplification was performed using the Tyramide Signal Amplification kit (PerkinElmer) as described previously (Sato et al., 2012). To label cone matrix sheath, retinal sections were incubated with $50 \mu \mathrm{g} / \mathrm{ml}$ fluorescein-tagged or rhodamine-tagged PNA (Vector Laboratories) for $1 \mathrm{~h}$ at room temperature. Nuclei were counterstained with 4' -6' -diamidino-2-phenylinodole (DAPI) or propidium iodide (PI) for 10 or $30 \mathrm{~min}$. After washing three times in Tw-PBS, sections were mounted with Fluoromount-G (SouthernBiotech), and fluorescent signals captured with a Zeiss LSM-510 Meta laser confocal microscope with a $20 \times$ or a $40 \times$ oil-immersion objective lens. Numbers and length of PNA-stained cone outer segments and numbers of short or middle wavelength cone opsin (S- or M-opsin)positive cone outer segments in whole retinal sections were counted using an Olympus BX61VS microscope equipped with VS-ASW FL software.

Transmission electron microscopy. Retinas were prepared for electron microscopy according to published procedures (Gordon and Bazan, 1993; Jin et al., 2009). Briefly, mice eyes were placed in a fixative $(2 \%$ paraformaldehyde and $2 \%$ glutaraldehyde in $0.1 \mathrm{~m}$ sodium cacodylate buffer) overnight at $4^{\circ} \mathrm{C}$. After removing anterior segment, eyecups were divided through the optic nerve along the vertical meridian. The resulting half eyecups were returned to the fixative for $1 \mathrm{~h}$, postfixed in $1 \%$ $\mathrm{OsO}_{4}$ in cacodylate buffer for $1 \mathrm{~h}$, and dehydrated through an ethanol series to acetone. Tissue was embedded in an "Epon"-Araldite mixture, and $1-\mu \mathrm{m}$-thick survey sections were obtained. After contrasting with $1 \%$ toluidine blue in $1 \%$ sodium borate, areas of interest were selected. Ultrathin sections cut with a Leica Ultracut UCT ultramicrotome were collected on 200 mesh copper grids and stained with lead and uranium salts. Approximately 400 photoreceptors per retina were observed using an electron microscope (Tecnai G2 F30, FEI Co.) in a masked fashion. Photoreceptors showing cellular shrinkage and nuclear condensation were defined as apoptotic cells, whereas photoreceptors associated with cellular and organelle swelling and discontinuities in nuclear membrane were defined as necrotic cells (Cortina et al., 2003; Trichonas et al., 2010).

Light microscopy. Hematoxylin and eosin (H\&E) staining for retinal cryosections was performed using the hematoxylin and eosin Y solutions (Sigma) as described previously (Sato et al., 2012). All stained sections were photographed with a Zeiss Axio Imager microscope using a $20 \times$ objective lens, a digital camera, and Axio Vision FL software.

Terminal deoxynucleotidyl transferase dUTP nick end labeling assay. Terminal deoxynucleotidyl transferase-mediated dUTP nick end label- 
Table 2. Primers used for qRT-PCR

\begin{tabular}{lll}
\hline Gene & Forward primer $\left(5^{\prime}-3^{\prime}\right)$ & Reverse primer $\left(5^{\prime}-3^{\prime}\right)$ \\
\hline TNF- $\alpha$ & AAAATTCGAGTGACAAGCCTGTAG & CCCTTGAAGAGAACCTGGGAGTAG \\
TNF-receptor 1 & GCCGGATATGGGCATGAAGC & TGTCTCAGCCTCACTTGAC \\
RIP1 & TGTCATCTAGCGGGAGGTG & TCACCACTCGACTGTGTCTCAG \\
RIP3 & CTCCGTGCCTTGACCTACTG & AACCATAGCCTTCACCTCCC \\
18s rRNA & TTTGTTGGTTTCGGAACTGA & CGTTTATGGTGGAACTACGA \\
\hline
\end{tabular}

ing (TUNEL) assay was performed using the in situ cell death detection kit (Roche) following the manufacture's protocol. Briefly, retinal cryosections washed with $0.1 \%$ sodium citrate in $0.1 \%$ Triton X100-PBS were incubated with terminal deoxynucleotidyl transferase (TdT) and fluorescein-dUTP for $1 \mathrm{~h}$ at $37^{\circ} \mathrm{C}$. After rinsing three times in Tw-PBS, nuclei were counterstained with DAPI and the sections mounted. Retinal sections of wild-type (WT) mice injected with $N$-methyl- $N$-nitrosourea (NMU), a strong inducer of photoreceptor degeneration (Smith et al., 1988), were used as the TUNEL-positive control.

Immunoblot analysis. Ten or $20 \mu \mathrm{g}$ of mouse retinal proteins were separated in an 8,10 , or $12 \%$ polyacrylamide gel by the SDS-PAGE, and transferred onto an Immobilon-P membrane (Millipore). The membrane was incubated in blocking buffer, primary antibody, and secondary antibody as described previously (Jin et al., 2007). Immunoblots were visualized with an enhanced ECL-Prime kit by scanning the membrane in an ImageQuant LAS4000 (GE Healthcare). The chemiluminescence intensity of each band was measured using ImageQuant TL software (GE Healthcare). A series of varying amounts of retinal proteins $(1.25-40 \mu \mathrm{g})$ prepared by twofold serial dilution was used to obtain a linear calibration curve.

Quantitative reverse transcription-PCR. Total RNA was extracted from mice retinas using the PureLink RNA Mini Kit (Invitrogen), and was reverse-transcribed to first-strand cDNA using SuperScript III (Invitrogen). Quantitative PCR (qPCR) was performed on a C1000 Thermal Cycler (Bio-Rad) using the iQ SYBR Green Supermix (Bio-Rad) and 0.3 $\mu \mathrm{M}$ primer sets specific for TNF- $\alpha$, TNF- $\alpha$ receptor 1 (TNFR1), RIP1, RIP3, and $18 \mathrm{~S}$ rRNA. Sequences of the primers are shown in Table 2. Four mice of each genotype were analyzed and all samples were run in duplicates. Starting templates were normalized after determining $18 \mathrm{~S}$ rRNA $C t$-values for each sample. Relative mRNA levels of TNF- $\alpha$, TNFR1, RIP1, and RIP3 were determined from the $\Delta C t$ values.

ELISA. The contents of TNF- $\alpha$ in retinal homogenates and in the IPM soluble fraction of WT and Irbp ${ }^{-1-}$ mice were determined using the ELISA kit (Invitrogen) and a SpectraMax 190 reader (Molecular Devices) according to manufacturer's instruction.

Statistical analysis. Statistical significance was determined with an unpaired, two-tailed Student's $t$ test. $p$ values $<0.05$ were considered to be statistically significant. Data are showed as the mean \pm SD unless otherwise noted.

\section{Results}

\section{Cone photoreceptor degeneration in $\operatorname{Irbp} p^{-1-}$ retina}

Although rod photoreceptor degeneration in $\operatorname{Irbp} p^{-1-}$ mice is well established (Liou et al., 1998; Ripps et al., 2000; Jin et al., 2009; Wisard et al., 2011), cone photoreceptor degeneration is controversial and inconclusive (Jin et al., 2009; Parker et al., 2009; Wisard et al., 2011). We therefore compared cone photoreceptor morphology in 4-week-old WT and Irbp ${ }^{-1-}$ mice. Quantitative measurements of length and numbers of cone photoreceptor matrix sheathes labeled with fluorescein-tagged PNA showed that both length and numbers of cone sheath were significantly reduced in $I r b p^{-1-}$ retina compared with age-matched WT retina (Fig. 1A-C).

To confirm this result we performed immunocytochemistry using antibodies against $\mathrm{M}$-opsin or S-opsin. Consistent with the results of PNA staining, the length and numbers of short and middle wavelength cone photoreceptor (S-cone and M-cone) outer segments (OS) were significantly reduced in $I r b p^{-1-}$ retina compared with those in WT retina (Fig. 1D-F). The average densities of M-cones in the Irbp ${ }^{-1-}$ inferior or superior retinas were reduced 30 or $31.5 \%$, respectively, compared with those in WT mice (Fig. 1E). S-cone densities in the $\mathrm{rrbp}^{-1-}$ inferior or superior retinas were reduced $\sim 26$ or $21.5 \%$, respectively (Fig. $1 F)$. The outer nuclear layers (ONL), stained with DAPI, were reduced in thickness to 6-8 nuclei in $\operatorname{Irbp}^{-1-}$ retinas versus 10-12 in WT (Fig. 1A,D), confirming that rod photoreceptors had degenerated in $I r b p^{-1-}$ mice.

\section{TNF- $\alpha$ and its receptor 1 are increased in the} interphotoreceptor matrix (IPM) and retinas of $I r b p^{-/-}$mice Since TNF- $\alpha$ is an important extracellular factor that can induce cellular apoptosis and/or necrosis, we tested whether TNF- $\alpha$ was increased in Irbp ${ }^{-1-}$ interphotoreceptor matrix (IPM) and retinas. ELISA showed that the contents of TNF- $\alpha$ in 4 -week-old Irbp ${ }^{-1-}$ IPM and retinas were increased more than 10-fold and fivefold, respectively, compared with those in wild-type IPM and retinas (Fig. 2A).

TNFR1 is the main cellular membrane receptor mediating the TNF- $\alpha$-induced cell death signal (Ashkenazi and Dixit, 1998). We therefore tested whether TNFR1 is increased in 4-week-old Irbp $p^{-1-}$ retinas. Immunoblot analysis showed that the content of TNFR1 in the Irbp ${ }^{-1-}$ retinas was $\sim 2.5$-fold higher than that in WT retinas (Fig. 2B). Consistent with this result, immunohistochemistry showed that immunofluorescence intensity of TNFR1 in the outer plexiform layer (OPL) of the $\mathrm{rrbp}^{-1-}$ retinas was significantly stronger than that in WT OPL (Fig. 2C). Moreover, some Irbp ${ }^{-1-}$ photoreceptor OS, but not WT photoreceptor OS, were positive for TNFR1 immunostaining (Fig. 2C). Higher-magnification images revealed that the Ir $b p^{-1-}$ OS positive for TNFR1 were also positive for PNA staining (Fig. 2D), indicating that TNFR1 is localized to some cone OS in $\operatorname{Irbp}{ }^{-1-}$ mice.

To test whether the increased protein levels of TNF- $\alpha$ and TNFR1 involve transcriptional induction, we performed quantitative reverse transcription-PCR (qRT-PCR). The contents of TNF- $\alpha$ and TNFR 1 mRNAs in Irbp ${ }^{-1-}$ retinas at P14 were similar to those in WT retinas (Fig. 2E). However, these mRNAs were upregulated at least $50 \%$ in 4 - and 8 -week-old $I r b p^{-1-}$ retinas compared with age-matched WT retinas (Fig. 2E), suggesting that transcriptional induction contributed to the elevation of TNF- $\alpha$ and TNFR1 proteins in 4 -week-old $\operatorname{Irbp} p^{-1-}$ retinas.

Apoptosis is involved in photoreceptor degeneration but is not the major cell death form in $\operatorname{Ir} b p^{-/-}$retina

A previous study showed that apoptosis is involved in photoreceptor degeneration in Irbp ${ }^{-1-}$ mice (Wisard et al., 2011). To test whether the photoreceptor degeneration in $\operatorname{Irbp}{ }^{-/-}$mice is mainly caused by apoptotic cell death, we performed TUNEL assay on retinal sections of WT and $\operatorname{Irbp}{ }^{-1-}$ mice. WT mice treated with NMU, a strong inducer of retinal degeneration (Smith et al., 1988), served as a positive control for photoreceptor apoptosis. As expected, a majority of photoreceptors in the NMU-treated mice were strongly positive for TUNEL (Fig. 3A), whereas WT retinal sections from untreated mice contained only one or no TUNEL-positive photoreceptors (Fig. $3 B, C$ ). In contrast, we observed that the counts of TUNEL-positive photoreceptors in $I r b p^{-1-}$ retinas were much smaller than those in the NMU-treated mice but much greater than those in untreated WT mice (Fig. 3A-C). The average numbers of TUNEL-positive photoreceptors in each retinal section of $\operatorname{Irbp} p^{-/-}$mice were $\sim 10$ per section (Fig. 3C). 
A

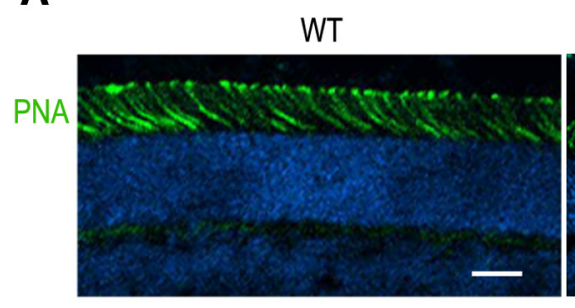

C

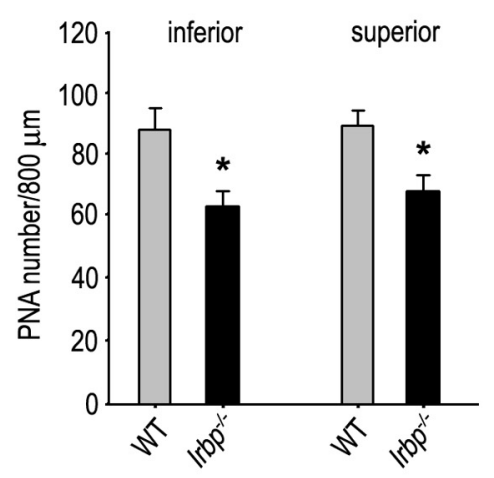

E

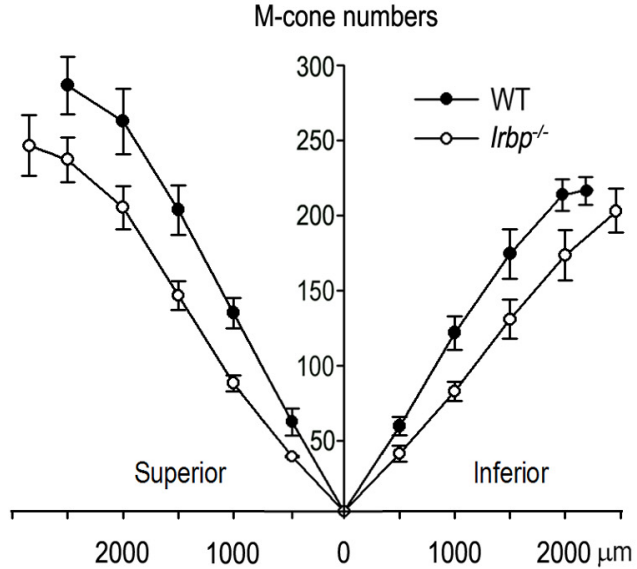

$1 r b p^{-/-}$

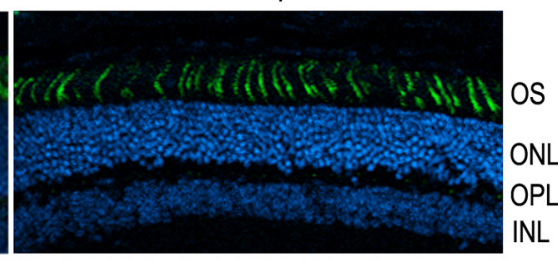

D

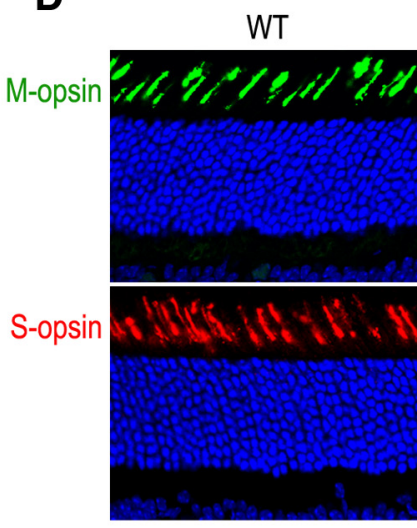

F

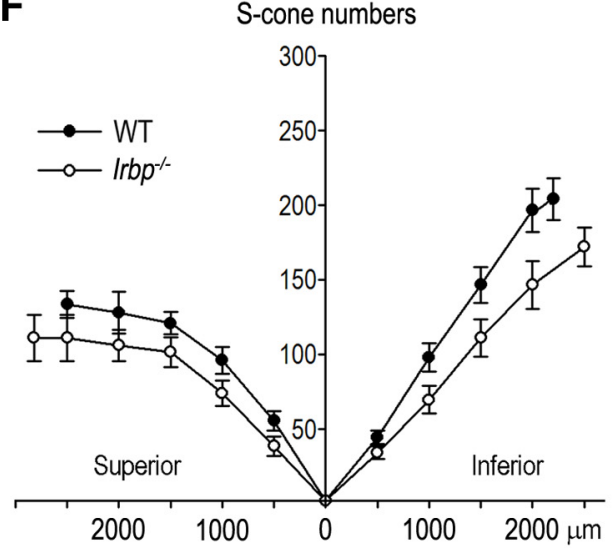

Figure 1. Cone and rod degeneration in $/ r b p^{-1-}$ retinas. $A$, Cone matrix sheathes in the superior retinas of 4-week-old WT and $/ r b p^{-~} /-$ mice were stained with fluorescein-tagged PNA. Nuclei were counterstained with DAPI (blue). OS of photoreceptors, ONL, OPL, and INL are indicated. Scale bar, $20 \mu \mathrm{m}$. $\boldsymbol{B}$, Histograms showing length of PNA-positive cone matrix sheathes in the central retinas of WT and $/ r b p^{-I-}$ mice. C, Histograms showing counts of PNA-positive cone matrix sheathes in $800 \mu m$ width regions of the inferior or superior retinas of WT and $/ r b p-1-$ mice. Asterisks indicate statistically significant differences between WT and mutant retinas ( $p<0.01$ ). Error bars denote $S D(n=4)$. $D$, Representative immunohistochemistry showing M-opsin (green)-positive cone $0 S$ in the superior and S-opsin (red)-positive cone OS in the inferior retinas of 4-week-old WT and Irbp ${ }^{-1-}$ mice. Scale bar, $20 \mu \mathrm{m}$. $\boldsymbol{E}, \boldsymbol{F}$, Counts of cone OS positive for M-opsin or S-opsin. Numbers on the $x$-axis indicate distance from optic nerve head. Error bars denote SD $(n=3)$.

Although the majority of TUNEL-positive cells are considered to be apoptotic (Chautan et al., 1999), TUNEL-positive cells also contain some necrotic cells in culture and ischemic animal experiments (Kelly et al., 2003). To confirm apoptosis is involved in degeneration of photoreceptors in $I r b p^{-I-}$ retina, we performed electron microscopic analysis. We observed apoptotic photoreceptors in Irbp ${ }^{-1-}$ retinas, but not in WT retinas (Fig. 3D). The average count of apoptotic photoreceptors per 400 photoreceptors observed was two and zero in $\operatorname{Irbp}^{-1-}$ and WT retinal sections, respectively. These data reveal that apoptosis is involved in the degeneration of $I r b p^{-1-}$ photoreceptors. We also observed similar numbers of necrotic photoreceptors under the same condition (Fig. 3D).

Caspase- 3 protease is a key mediator of the caspase-dependent apoptosis. To test whether caspase-3 is activated in Irbp ${ }^{-1-}$ ret- ina, we analyzed production of 120 and $150 \mathrm{kDa}$ fragments of $\alpha$-fodrin, an endogenous substrate of caspase-3 (Waterhouse et al., 1998). Immunoblot analysis showed that the $120 \mathrm{kDa}$ fragment of $\alpha$-fodrin was not increased in $I r b p^{-1-}$ retinas compared with WT retinas (Fig. 4A). In contrast, we observed a significant increase of the $120 \mathrm{kDa}$ fodrin fragment in the retinal degeneration model of mice treated with NMDA (Fig. 4A). Immunohistochemistry using an antibody against active caspase- 3 detected the activated caspase-3 in $I r b p^{-1-}$ photoreceptor nuclei (Fig. $4 B$ ), but not in WT photoreceptor nuclei (Fig. 4B). The average numbers of active caspase-3-positive photoreceptor nuclei per retinal section were $\sim 0.3$ and 4 in WT and $I r b p^{-1-}$ retinas (Fig. $4 F)$, respectively.

Because activation of caspase-3 in $\operatorname{Irbp} \mathrm{p}^{-1-}$ retinas was not significant, we tested whether calpains and apoptosis-inducing 
A

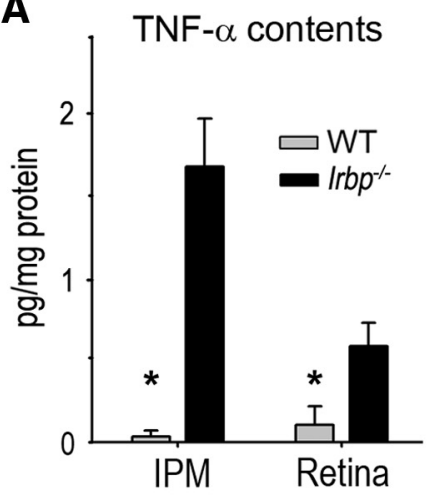

D

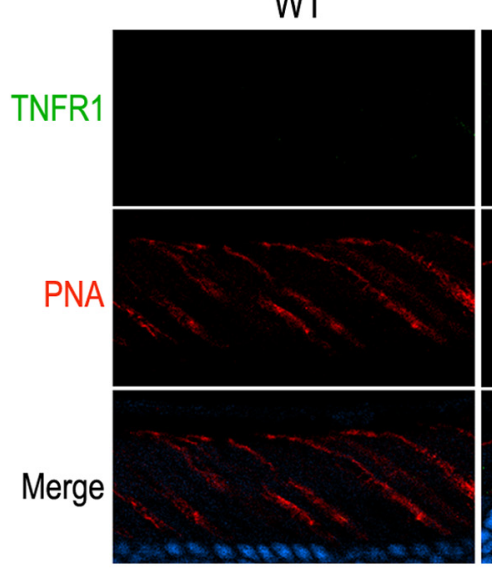

B

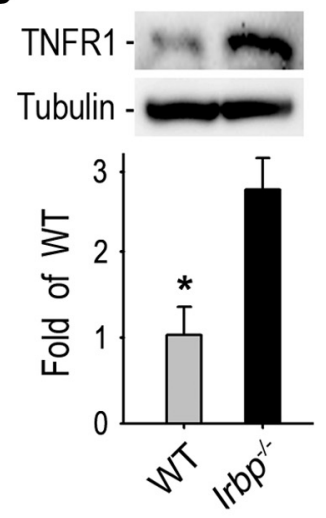

$\mathrm{Irbp}^{-1-}$

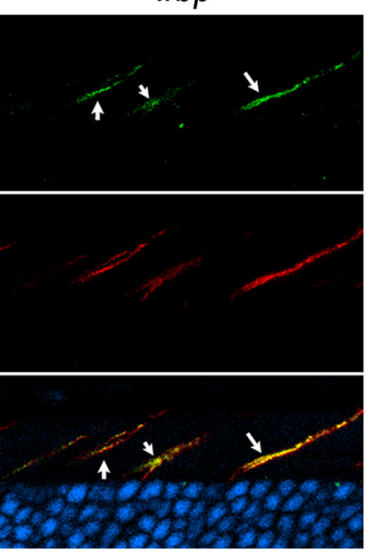

C

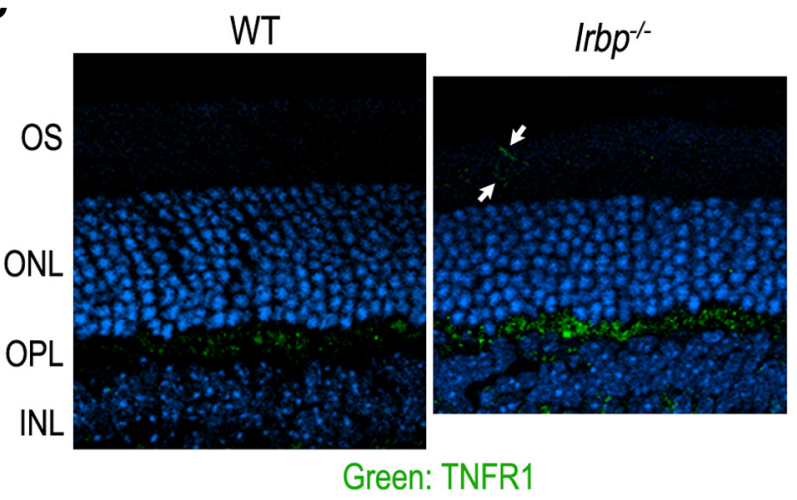

E

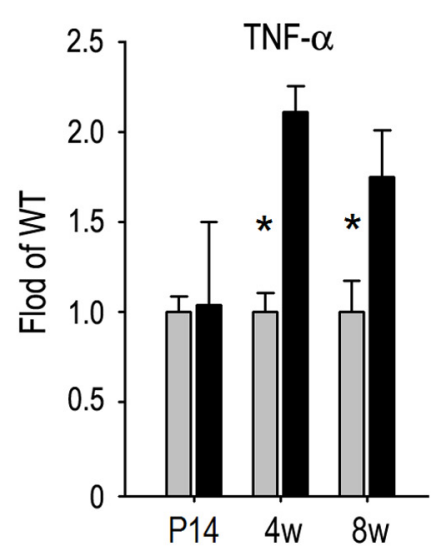

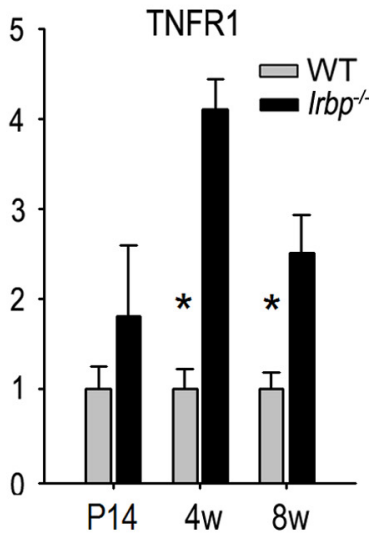

Figure 2. Upregulation of TNF- $\alpha$ and TNFR1 in Irbp ${ }^{-1-}$ retina. $A$, Amounts of TNF- $\alpha$ in 4-week-old (4w) WT and $/ r b p^{-1-}$ IPM and retinas were determined by the enzyme-linked immuno sorbent assay. Asterisks indicate significant differences between WT and mutant mice $(p<0.01)$. Error bars denote SD $(n=4)$. $\boldsymbol{B}$, Immunoblot analysis of TNFR1 in $4 \mathrm{~W}-0$ ld WT and $/ r b p-I-$ retinas. Relative expression levels of TNFR1 in WT and $/ r b p^{-1-}$ retinas were normalized to tubulin levels in three independent experiments and shown in the histogram. $C$, Representative immunohistochemistry showing upregulation of TNFR1 in /rbp ${ }^{-1-}$ retina. Arrows indicate photoreceptor OS positive for TNFR1. D, Double staining of TNFR1 (green) and rhodamine-tagged PNA (red) in WT and $I r b p^{-I-}$ retinal sections. Arrows indicate photoreceptor OS positive for both TNFR1 and PNA staining. $\boldsymbol{E}$, Relative expression levels of TNF- $\alpha$ and TNFR1 mRNAs in WT and Irbp ${ }^{-I}-$ retinas at the indicated ages were determined by quantitative RT-PCR and were normalized to $18 \mathrm{~S}$ rRNA levels. Error bars designate SD $(n=4)$.

factor (AIF), which are involved in caspase-independent apoptosis, were activated in $\operatorname{Irb} p^{-1-}$ retina. The $\mathrm{m}$-calpains and $\mu$-calpains are $80 \mathrm{kDa}$ proenzymes, and undergo an autolytic cleavage to produce their $76 \mathrm{kDa}$ active proteases in apoptotic cells (Goll et al., 2003). We analyzed production of the cleaved active calpains in $I r b p^{-1-}$ retinas. Immunoblot analysis showed that intensities of the active $\mathrm{m}$-calpains and $\mu$-calpains (76-78 $\mathrm{kDa}$ fragments) were not increased in 4 -week-old $\mathrm{rrbp}^{-1-}$ retinas compared with age matched WT retinas (Fig. $4 C$ ).

AIF released from mitochondria also activates the caspaseindependent apoptotic pathway after translocating to the nucleus (Susin et al., 1999). We were able to find AIF-positive photoreceptor nuclei in $I r b p^{-1-}$ retinas by immunohistochemistry (Fig. $4 D$ ), but we could not find any AIF-positive photoreceptor nuclei in WT retinas (Fig. 4E). The average counts of AIF-positive nuclei in the $I r b p^{-1-}$ outer nuclear layer were $\sim 3.5$ per retinal section (Fig. 4G). These results are consistent with the small count of TUNEL-positive cells in $\operatorname{Irbp} p^{-1-}$ retinas.

\section{RIP1-mediated necrosis contributes to the loss of cone and} rod in $\operatorname{Ir} b p^{-1-}$ mice

The results described above indicate that apoptosis is an important mechanism leading to photoreceptor degeneration in $\operatorname{Irbp} p^{-1-}$ mice. However, the results also suggest that other cell death mechanism(s) is involved in the degeneration of $\operatorname{Irbp} p^{-1-}$ photoreceptors. Based on the transmission electron microscopy (TEM) observation (Fig. 3D), we hypothesized that necrotic cell death strongly contributes to the photoreceptor loss in Irbp ${ }^{-1-}$ mice.

The receptor interacting proteins kinases 1 and 3 (RIP1 and RIP3) are the key mediators of cellular necrosis (Cho et al., 2009; He et al., 2009; Zhang et al., 2009) and are elevated in retinas of photoreceptor degeneration animal models (Trichonas et al., 2010; Murakami et al., 2012). We therefore analyzed expression levels of RIP1 and RIP3 in P14, 4-week-old, and 8-week-old retinas. We first optimized immunoblot assay conditions based on the calibration curves shown in Figure 5, $A$ and $B$, and then determined relative contents of RIP1 and RIP3 in WT and Irbp ${ }^{-1-}$ retinas. Both RIP1 and RIP3 were not increased in $I r b p^{-1-}$ retinas at P14 (Fig. 5C); at this age thickness of the ONL in $\operatorname{Irbp} p^{-1-}$ mice is similar to that in WT mice (Wisard et al., 2011). In contrast, both RIP1 and RIP3 were increased at least twofold in 4-week-old and 8 -week-old Irbp ${ }^{-1-}$ retinas compared with age matched WT retinas (Fig. 5C). Consistent with this result, immunohistochemistry showed that the signal intensities of RIP3 in 4-week-old Irbp ${ }^{-1-}$ ONL were significantly higher than those in WT retinas (Fig. 5D). Double staining for RIP3 and PNA suggests that some RIP3-positive photoreceptors are cones (Fig. 5E).

To test whether the increased protein levels of RIP1 and RIP3 were induced by transcriptional upregulation, we measured their 
A

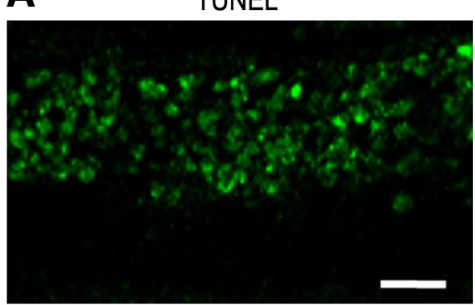

B

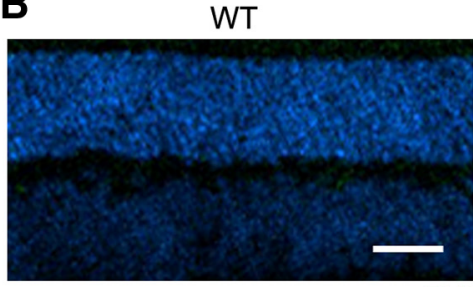

TUNEL

D

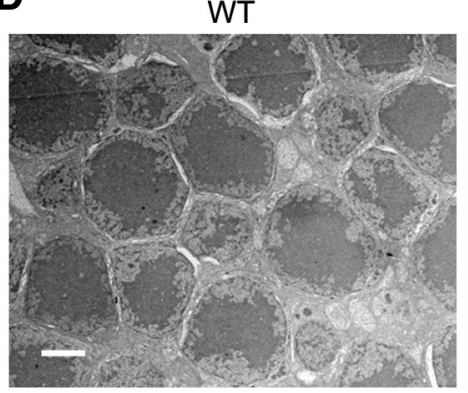

DAPI

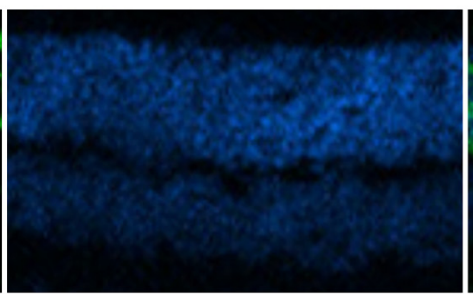

Irbp--

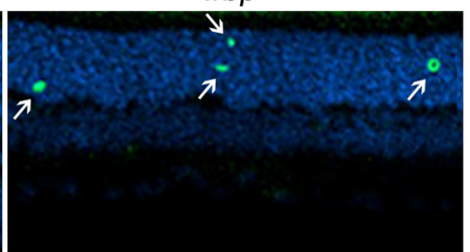

ONL

INL

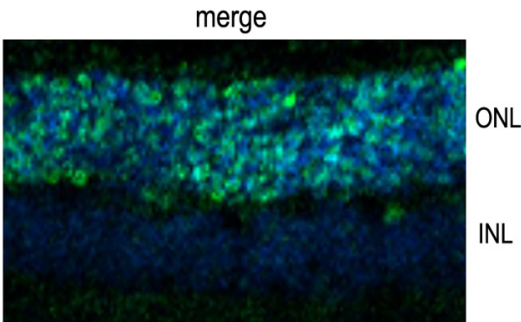

C

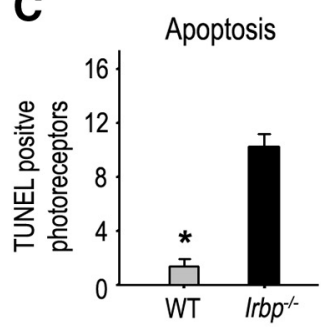

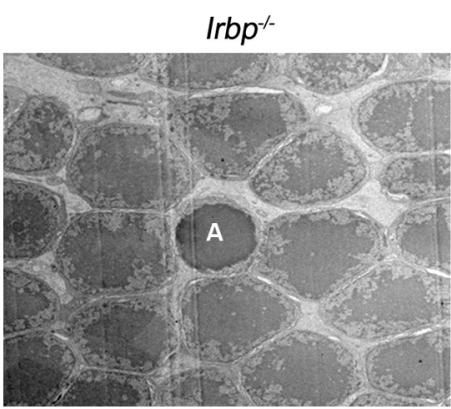

Irbp $^{-/-}$

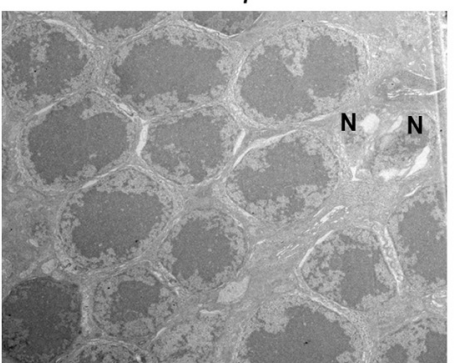

Figure 3. Apoptosis of photoreceptors in Irbp ${ }^{-1-}$ retina. $A$, Photoreceptor apoptosis (green label) in WT mice was induced with an injection of NMU, and was detected by TUNEL assay as a positive control. Nuclei were counterstained with DAPI. $\boldsymbol{B}$, Retinal sections from 4-week-old WT and $/ r b p^{-1}$ - mice were analyzed by TUNEL assay to detect photoreceptor apoptosis. Arrows indicate TUNEL-positive photoreceptors. Scale bars, $20 \mu \mathrm{m}$. C, Histogram showing the average counts of TUNEL-positive photoreceptors in a whole retinal section from 4-week-old WT and Irbp ${ }^{-I-}$ mice. $^{-}$ Asterisks indicate significant differences between WT and $/ r b p^{-1-}$ mice $(p<0.001)$. Error bars designate SD $(n=4)$. D, TEM photomicrographs of photoreceptors in 4-week-old WT and $/ r b p^{-1-}$ retinas. $A$ and $N$ in the images indicate apoptotic and necrotic cells, respectively. Scale bar, $2 \mu \mathrm{m}$.

mRNA contents in the retinas. Quantitative RT-PCR showed that mRNA contents of RIP3 in 4-week-old and 8-week-old Irbp ${ }^{-1-}$ retinas are significantly higher than those in age-matched WT retinas (Fig. $5 F$ ), suggesting that transcriptional induction of RIP3 occurs in the retina lacking IRBP.

If the increased RIP1 and RIP3 kinases contribute to photoreceptor necrosis in $I r b p^{-1-}$ mice, inhibition of these kinases should partially prevent photoreceptor loss in Irbp ${ }^{-1-}$ mice. To test this possibility, we systemically treated $\operatorname{Irbp} p^{-1-}$ mice with RIP1 inhibitors (Nec-1 and Nec-1s) and Nec-1i or vehicle controls. Light microscopic analysis showed that the thickness of the ONL in 8-week-old Irbp $p^{-1-}$ mice treated with Nec-1i for 6 weeks was $\sim 15.8 \mu \mathrm{m}$ thinner than that of WT mice, whereas the thickness of the ONL in the Nec-1s-treated mice was $6.4 \mu \mathrm{m}$ thicker than that of Nec-1i-treated mice (Fig. $6 A, B$ ), suggesting that loss of the ONL was reduced $40.5 \%$ in Nec-1s-treated mice compared with Nec-1i-treated mice. Similarly, ONL thickness in 4-weekold Irbp ${ }^{-1-}$ mice treated with Nec-1 for 2 weeks was significantly thicker than that of the vehicle (DMSO)-treated mice (Fig. 6C). Moreover, the density of cone outer segments, indicated by PNA labeling, was significantly increased in Nec-1s-treated mice compared with the Nec-1i and vehicle-treated mice (Fig. 6D,E), suggesting that $\mathrm{Nec}-1 \mathrm{~s}$ protected cone and rod photoreceptors from degeneration by inhibiting RIP1 kinase.

\section{Discussion}

This study focused on identification of cell death pathway(s) responsible for photoreceptor loss in Irbp ${ }^{-1-}$ mice. We found that caspase-dependent and -independent apoptosis are involved in degeneration of $I r b p^{-1-}$ photoreceptors. However, only a portion of the photoreceptor loss is caused by apoptotic cell death in $I r b p^{-1-}$ retina. In contrast, RIP kinase-mediated necrosis strongly contributes to cone and rod degeneration in Irbp ${ }^{-1-}$ mouse. This RIP-mediated photoreceptor necrosis may be activated by TNF- $\alpha$ and TNFR1 increased significantly in $\operatorname{Irbp}{ }^{-1-}$ retina.

TNF- $\alpha$ is an important proinflammatory cytokine. Extensive studies implicate TNF- $\alpha$ as a key mediator of cell death in brain and retinal neurodegenerative diseases (Tezel, 2008; Montgomery and Bowers, 2012). TNF- $\alpha$ is upregulated in the brain, RPE, retinal neurons, and glial cells by infection, injury, oxidative stress, and glaucomatous conditions (Tanihara et al., 1992; Tezel, 2008; Kaneko and Rao, 2012). Given that IRBP binds and protects 11-cis-retinal, 11-cis-retinol, and all-trans retinol (Bridges et al., 1984; Crouch et al., 1992), the retinols may undergo oxidation in the absence of IRBP. Consistent with this possibility, the relative content of all-trans retinal in $\operatorname{Irb} p^{-1-}$ retina is higher than that in WT retina (Jin et al., 2009). Because 11-cis-and all-trans retinals possess a highly reactive and cytotoxic aldehyde group, these molecules may cause tissue damage in the absence of IRBP and trigger upregulation of TNF- $\alpha$ in $\operatorname{Irbp} p^{-1-}$ retina.

Lack of IRBP also resulted in more than a tenfold increase of soluble TNF- $\alpha$ in Irbp $p^{-1-}$ IPM (Fig. $2 A$ ). It is known that the secreted soluble TNF- $\alpha$ is derived from the transmembrane TNF- $\alpha$ precursor through a proteolytical process by the TNF- $\alpha$ 
A

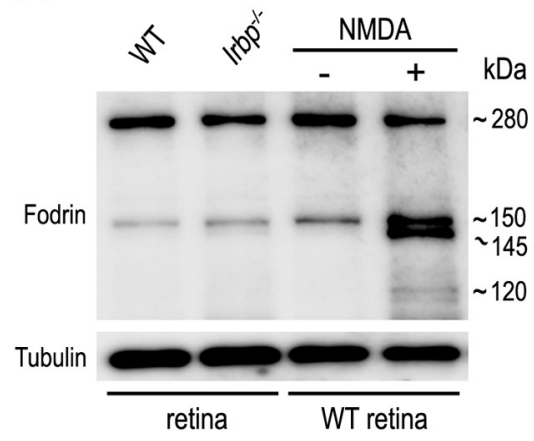

C

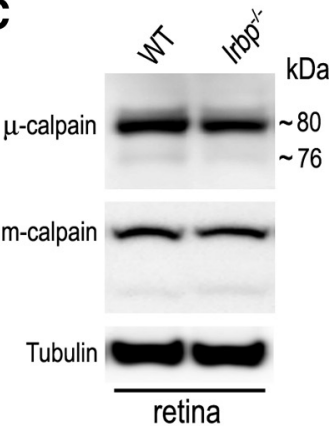

B

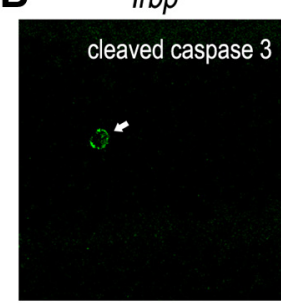

D

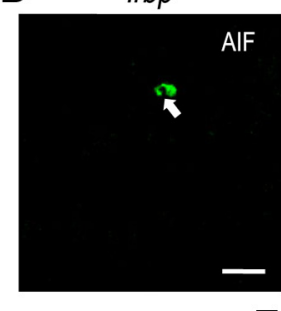

E

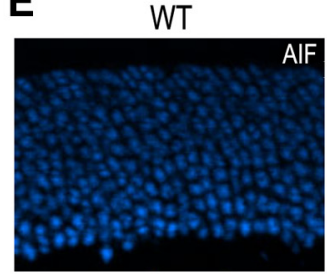

Irbp $p^{-1-}$

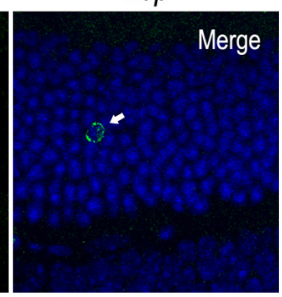

$1 r b p^{-/-}$

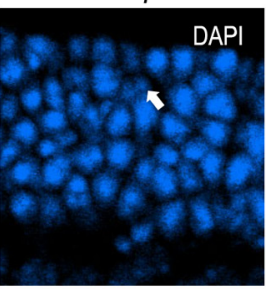

F

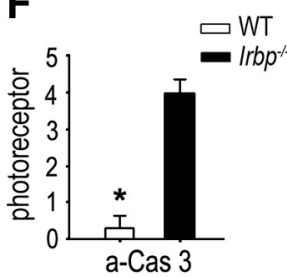

WT

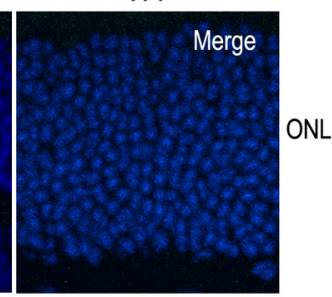

$1 \mathrm{rbp} \mathrm{p}^{-/-}$

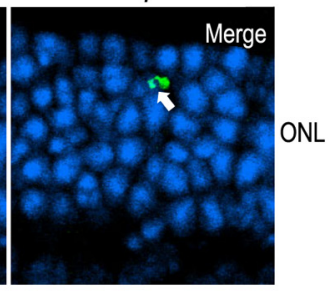

G

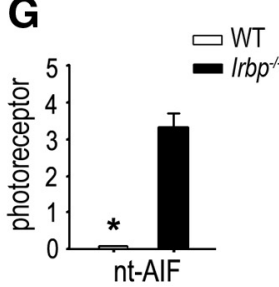

Figure 4. Caspase-dependent and -independent apoptotic pathways were activated in a few $/ r b p^{-/-}$photoreceptors. $\boldsymbol{A}$, Immunoblot analysis of $\alpha$-fodrin in 4-week-old WT and $/ r b p{ }^{-/-}$ retinas as well as in WT retinas treated $(+)$ or untreated $(-)$ with NMDA. Caspase-3-cleaved 120 and $150 \mathrm{kDa}$ fragments of $\alpha$-fodrin are indicated. Tubulin was detected as a loading control. $\boldsymbol{B}$, Immunohistochemistry showing the presence of active caspase-3 (green, arrow) in a nucleus of $/ r b p^{-1}$ - photoreceptor, but not WT photoreceptor. Nuclei were counterstained with DAPI (blue). C, Immunoblot analysis of m-calpains and $\mu$-calpains in WT and $/ r b p^{-1-}$ retinas. The $80 \mathrm{kDa}$ proenzyme and $76 \mathrm{kDa}$ active form of calpains are indicated. $\boldsymbol{D}$, Representative immunohistochemistry showing translocation of AIF into an $/ r b p^{-1-}$ photoreceptor nucleus (green, arrow). Scale bar, $5 \mu \mathrm{m}$. $E$, Immunohistochemistry showing the absence of AIF-positive nucleus in WT photoreceptors. $\boldsymbol{F}, \mathbf{G}$, Histograms showing the average counts of photoreceptors positive for active caspase 3 (a-Cas3) or nuclear-translocated AIF (nt-AIF) in a whole retinal section from WT and Irbp ${ }^{-1}$ - mice. Asterisks indicate significant differences between WT and $/ r b p^{-1-}$ mice $(p<0.001)$. Error bars designate SD $(n=4)$.

converting enzyme (TACE), a matrix metalloproteinase (Black et al., 1997; Moss et al., 1997). Since the expression level of TNF- $\alpha$ mRNA in Irbp ${ }^{-1-}$ retina is only twofold higher than that in WT retina (Fig. $2 E$ ), the $>10$-fold increase of soluble TNF- $\alpha$ may involve accelerated cleavage of the TNF- $\alpha$ precursor by TACE in the absence of IRBP. The mechanisms of how IRBP itself and the absence of IRBP regulate TNF- $\alpha$ expression and secretion are unknown at present and so need to be elucidated by further studies.

TNF- $\alpha$ exerts its roles through its two distinct transmembrane receptors, TNFR1 and TNFR2 (Montgomery and Bowers, 2012). TNFR1 is expressed in almost all types of cells whereas TNFR2 is expressed at low levels in immune system cells (Van Hauwermeiren et al., 2011). TNFR1 can be activated by both membranebound and soluble TNF- $\alpha$ and serves as a major mediator of TNF- $\alpha$ signaling (Van Hauwermeiren et al., 2011). In a retinal ischemia mouse model, TNFR1 has been shown to be upregulated and aggravate neuronal death (Fontaine et al., 2002). We found that TNFR1 is significantly upregulated in the Irbp ${ }^{-1-}$ retina, including some cone photoreceptors, via transcriptional induction (Fig. 2C-E). TNF- $\alpha$ and TNFR1 exhibit their pathological roles by promoting apoptotic and necrotic neuronal death in neurodegenerative diseases (Montgomery and Bowers, 2012). In this study, we observed that counts of TUNEL-positive photoreceptors in 4 -week-old $I r b p^{-1-}$ retinas were significantly higher than those in WT retinas (Fig. $3 B$ ). However, the total counts in a whole section of $I r b p^{-/-}$retina were only $\sim 10$ (Fig. $3 C)$. This number is similar to the data reported previously
(Wisard et al., 2011). We also found that there were only approximately four active caspase-3-positive photoreceptor nuclei in a whole $I r b p^{-1-}$ retinal section (Fig. $4 F$ ). Although this number is higher than that in WT retina (Fig. $4 F$ ), it is not enough to explain the $35-45 \%$ loss of photoreceptors in Irbp ${ }^{-1-}$ mice (Liou et al., 1998; Ripps et al., 2000; Jin et al., 2009; Wisard et al., 2011). The similar amounts of the caspase-3-cleaved $120 \mathrm{kDa}$ fragment of $\alpha$-fodrin in WT and Irbp $p^{-1-}$ retinas (Fig. $4 A$ ) further confirm that caspase-dependent apoptosis is not the major mechanism leading to severe photoreceptor loss in $\operatorname{Irbp} p^{-1-}$ mice.

AIF is a critical mediator of the caspase-independent apoptosis. AIF is confined to mitochondria but translocates to the nuclei in apoptotic cells (Susin et al., 1999). The AIF nuclear translocation requires activation calpains (Susin et al., 1999; Goll et al., 2003). In apoptotic cells, $\mathrm{m}$-calpains and $\mu$-calpains produce their highly active fragments $(76 \mathrm{kDa})$ through an autolytic cleavage (Goll et al., 2003). The active $76 \mathrm{kDa}$ fragments trigger nuclear-translocation of AIF (Susin et al., 1999; Goll et al., 2003). In this study, we observed that the amounts of the $76 \mathrm{kDa}$ fragments in Irbp $p^{-1-}$ retinas were similar to those in WT retinas (Fig. $4 C$ ). Consistent with this result, we observed that only 3-4 Irbp $p^{-1-}$ photoreceptors in a whole section contained AIF in their nuclei (Fig. 4G). These results suggest that both caspasedependent and -independent apoptosis are not the major mechanisms underlying severe photoreceptor loss in $\operatorname{Irbp} p^{-1-}$ retina.

A study by Wisard et al. (2011) supports this possibility. They observed that the counts of TUNEL-positive photoreceptors in Irbp ${ }^{-1-}$ retinas at P12-P22 were similar to or smaller than those 
A

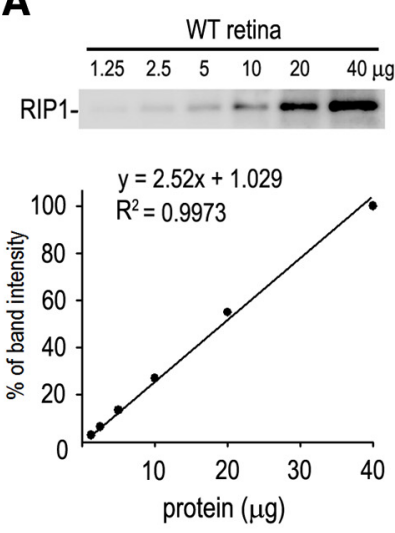

B

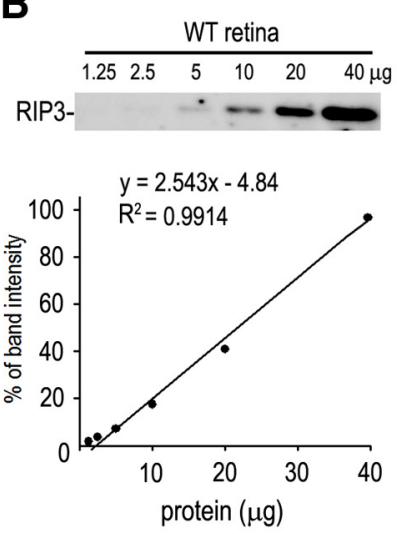

C
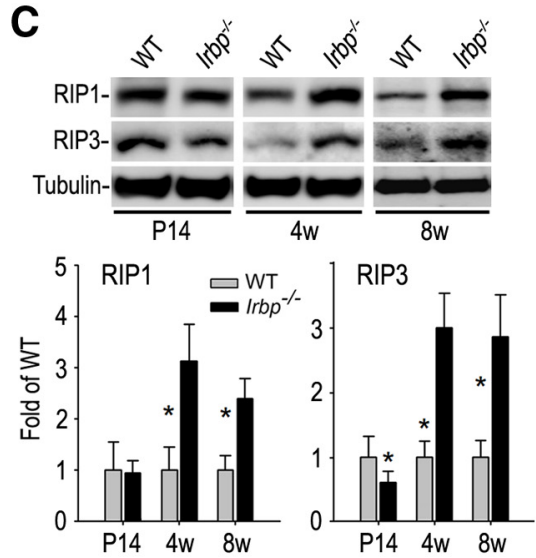

D WT

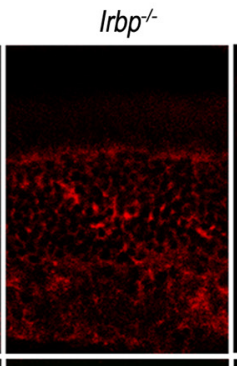

Irbp ${ }^{-1}+$ peptide
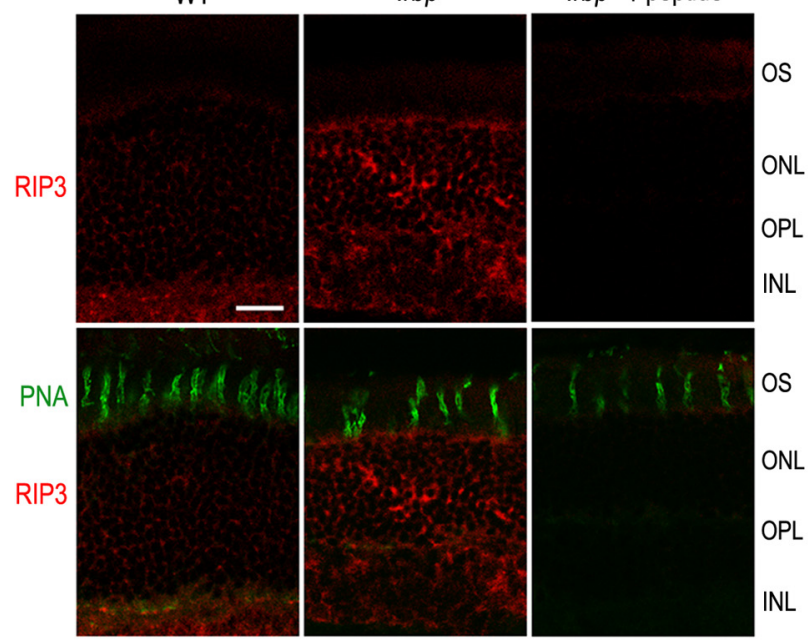

E

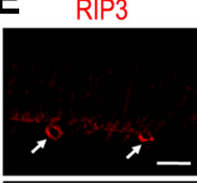

PNA
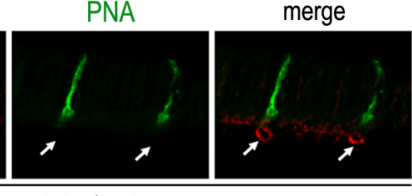

Irbp ${ }^{-/-}$retina

$\mathbf{F}$ Real-time RT-PCR
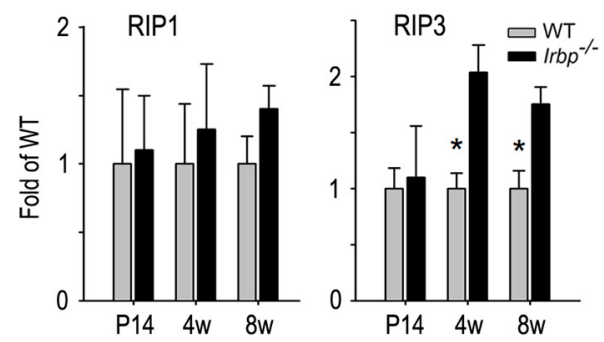

Figure 5. Upregulation of RIP1 and RIP3 kinases in $/ r b p^{-1-}$ retina. $A, B$, Calibration curves showing linearity of band intensities of RIP1 $(\boldsymbol{A})$ and RIP3 $(\boldsymbol{B})$ versus retinal protein amounts over the ranges $1.25-40 \mu \mathrm{g}$. The densitometry data from $40 \mu \mathrm{g}$ of protein was set as $100 \%$ signal intensity on the $y$-axis. C, Immunoblot analysis for RIP1 and RIP3 in retinas of WT and $/ r b p{ }^{-1-}$ mice at the indicated ages. Expression levels of RIP1 and RIP3 in Irbp ${ }^{-1-}$ retinas were normalized to tubulin, and shown as fold of those in WT retinas. Asterisks indicate significant differences between WT and $/ r b p^{-1-}$ mice $(p<0.01)$. Error bars designate SD $(n=4)$. D, Representative immunohistochemistry showing increased expression levels of RIP3 in the 0NL, OPL, and INL of /rbp ${ }^{-1-}$ retinal sections stained with a RIP3 antibody in the presence (+ peptide) or absence of immunogenic peptides. Cone matrix sheathes were stained with PNA (green). Scale bar, $10 \mu \mathrm{m}$. $\boldsymbol{E}$, High-magnification images of double staining for RIP3 (red) and PNA (green). Arrows indicate expression of RIP3 in cones. Scale bar, $5 \mu \mathrm{m}$. $F$, Expression levels of RIP1 and RIP3 mRNAs in $/ r b p p^{-/ \text {- }}$ retinas at the indicated ages were determined by quantitative RT-PCR, normalized to $18 \mathrm{~S} r \mathrm{RNA}$, and expressed as fold of their expression levels in WT retinas. Asterisks indicate significant differences between WT and $/ r b p^{-1-}(p<0.01)$. Error bars indicate SD $(n=4)$.

in age matched WT retinas. Although the counts of TUNELpositive photoreceptors in $\mathrm{Irbp} \mathrm{p}^{-1-}$ retinas at P25 were higher than those in WT retinas, the total number was only $\sim 15$ per whole retinal section. After P27, TUNEL-positive photoreceptor counts in $I r b p^{-1-}$ retinas were similar to or slightly higher than those in WT retinas. These data suggest that an alternative cell death pathway is involved in the progressive photoreceptor degeneration in Irbp ${ }^{-1-}$ mice.

Accumulating evidence suggests that RIP kinase-mediated necrosis contributes to retinal degeneration in animal models for $\mathrm{RP}$, retinal detachment, and ischemic reperfusion (Rosenbaum et al., 2010; Trichonas et al., 2010; Murakami et al., 2011, 2012). In these animal models, RIP1 and RIP3 kinases are significantly upregulated (Trichonas et al., 2010; Murakami et al., 2012). Consistent with these studies, we observed that expression levels of both RIP1 and RIP3 in 4-week-old Irbp ${ }^{-1-}$ retina were increased $>3$-fold compared with those in WT retina (Fig. 5C). Real-time RT-PCR suggests that transcriptional induction is involved in the increased expression levels of RIP3, but not RIP1 (Fig. 5F). The mechanism that results in elevation of RIP1 kinase in $\mathrm{rrbp}^{-1-}$ retinas is unknown at present. It may be associated with inhibition of RIP1 degradation mediated by ubiquitination. The ubiquitin-editing enzyme A20 has been shown to promote ligation of K48-linked ubiquitin chains to RIP1, thereby targeting RIP1 for proteasomal degradation (Wertz et al., 2004). Disruption of A20 results in increased RIP1 expression levels and susceptibility of cells to programmed death induced by TNF- $\alpha$ (Lee et al., 2000; Wertz et al., 2004). Further studies are needed to clarify whether ubiquitination-mediated degradation of RIP1 is inhibited in the Irbp $p^{-1-}$ retinas. Nevertheless, significant prevention of cone and rod photoreceptors by Nec-1 and Nec-1s (Fig. 6) suggests that RIP kinase-mediated necrosis is a critical mechanism underlying photoreceptor degeneration in Irbp $p^{-1-}$ mice, although we could not rule out the possibility that the autophagy-mediated cell death is also involved in the retinal degeneration in $I r b p^{-1-}$ mice.

Recently, Parker et al. (2009) reported that cone densities in Irbp ${ }^{-1-}$ mice with black coat color (C57BL/6 genetic background) are similar to those in C57BL/6 mice. In the previous and present studies, we observed that cone densities in 4-week-old 
A

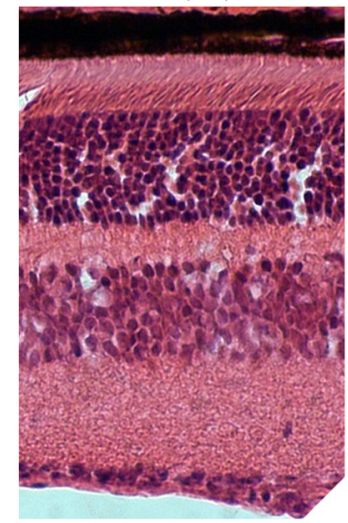

B

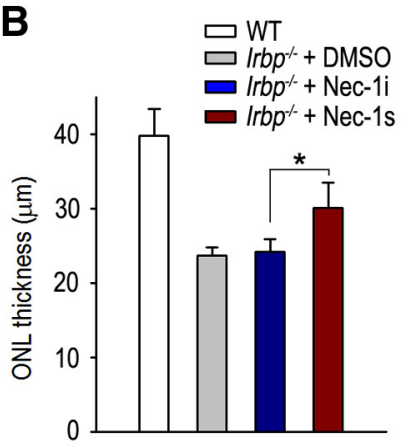

D
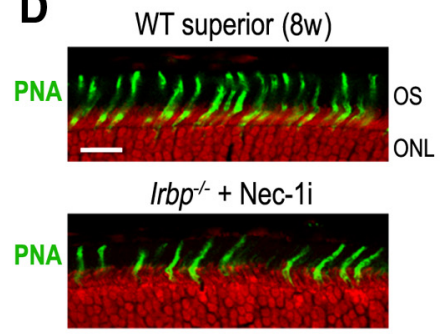

Irbp- ${ }^{-/}+\mathrm{Nec}-1 \mathrm{~s}$

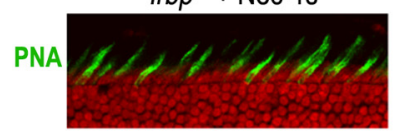

DMSO

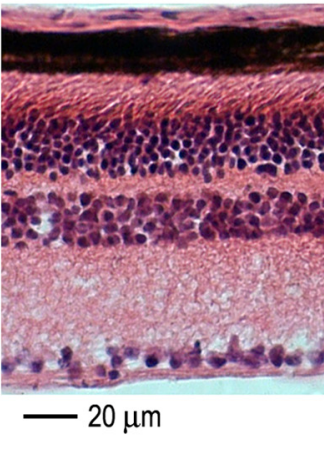

C
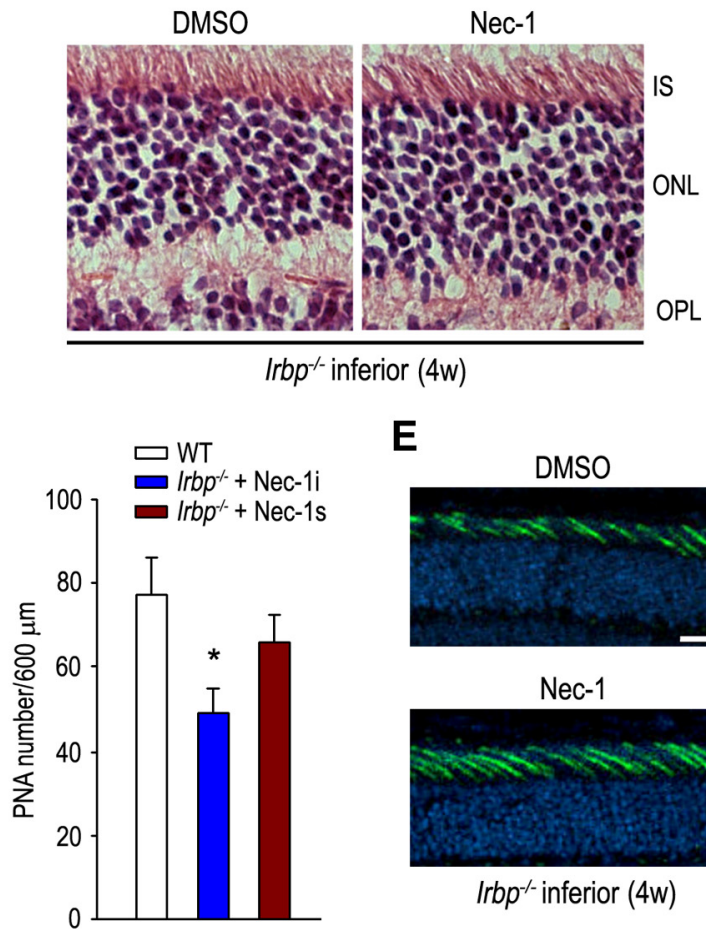

E

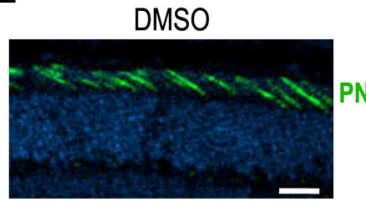

$\mathrm{Nec}-1$

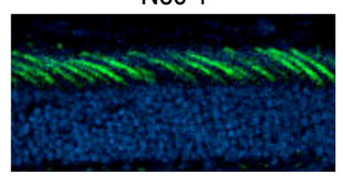

Irbp ${ }^{-/ \text {inferior }(4 w)}$
Nec-1i

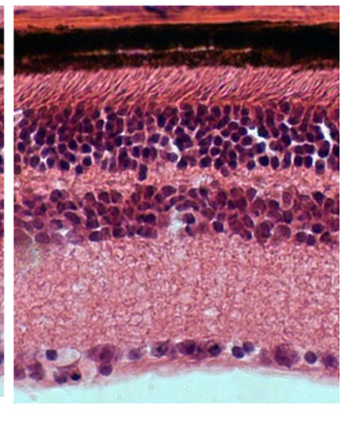

Irbp ${ }^{-1-}$ superior $(8 \mathrm{w})$

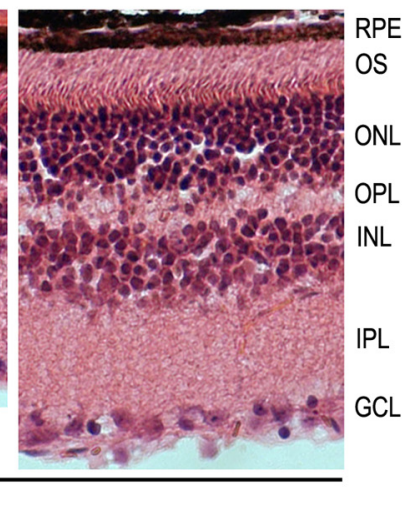

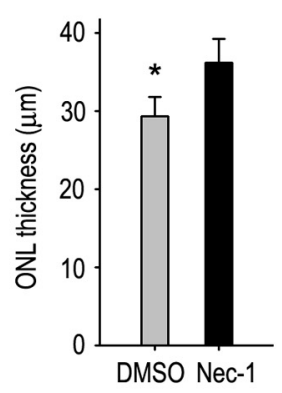

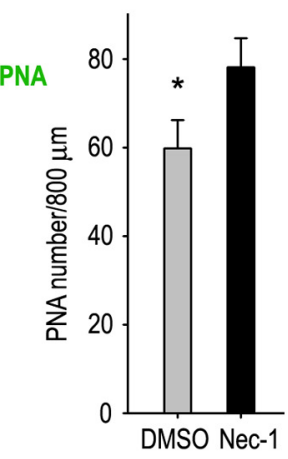

Figure 6. Protection of cone and rod photoreceptors by RIP1 inhibitors in Irbp ${ }^{-1-}$ mice. A, H\&E staining of retinal sections from 8-week-old (8w) WT and $/ r b p^{-I-}$ mice treated with DMSO, $\mathrm{Nec}-1 \mathrm{i}$, or Nec-1s. GCL, Ganglion cell layer. $\boldsymbol{B}$, Histogram showing the average thickness of the ONL in superior retinas from 8W-old WT and Irbp ${ }^{-1-}$ mice treated with the indicated reagents. Asterisks indicate statistically significant differences between mice treated with Nec-1i or Nec-1s $(p<0.05)$. Error bars denote SD $(n=6)$. C, H\&E staining of retinal sections of 4w-old Irbp ${ }^{-1-}$ mice treated with DMSO or Nec-1. The average thickness of the $0 \mathrm{NL}$ in the inferior retinas of the mice is shown in the histogram. Asterisks indicate significant differences between the two treatments $(p<0.05)$. Error bars denote SD $(n=6)$. IS, Inner segment of photoreceptor. D, PNA staining (green) of the superior retinas of $8 \mathrm{~W}$-old WT and $/ \mathrm{rbp}{ }^{-1-}$ mice treated with Nec-1i or Nec-15. Nuclei were counterstained with propidium iodide (red). Numbers of PNA-positive cone matrix sheathes in a $600 \mu \mathrm{m}$ width region of the superior retinas are shown in the histogram. Scale bar, $20 \mu \mathrm{m}$. E, PNA staining of the inferior retinas of $4 \mathrm{w}$-0ld $/ \mathrm{rbp}{ }^{-1-}$ mice treated with DMSO or Nec-1. Nuclei were counterstained with DAPI (blue). Numbers of PNA-positive cone sheathes in $800 \mu \mathrm{m}$ width region of the mice inferior retinas are shown in the histogram. Scale bar, $10 \mu \mathrm{m}$.

Irbp ${ }^{-1-}$ mice with agouti coat color (129S genetic background) were significantly reduced compared with those in $129 \mathrm{~S} 2 / \mathrm{Sv}$ mice. As Wisard et al. suggested (2011), this inconsistency may be caused by the distinct genetic backgrounds of the $I r b p^{-1-}$ mice. RPE65 that synthesizes 11-cis-retinol (Jin et al., 2005; Moiseyev et al., 2005; Redmond et al., 2005) is present in C57BL/6 mouse S-cones, but not 129Sv mouse S-cones (Tang et al., 2011). Because of these different expression levels of RPE65, amounts of 11-cis-retinal essential for cone survival (Rohrer et al., 2005; Znoiko et al., 2005) may be different in C57BL/6 cones versus 129 Sv mice cones. We also observed partial mislocalization of $\mathrm{M}$-opsin in $I r b p^{-1-}$ superior retinas (Fig. 1D), which is similar to the images published by Parker et al. (2009). Since only a small portion of M-opsins is mislocalized, this mislocalization is not the cause of $\mathrm{M}$-cone degeneration in the $\mathrm{Irbp} \mathrm{p}^{-1-}$ retinas, while severe cone opsin mislocalization caused by lack of 11-cis-retinal seems to be the main cause of cone degeneration in Rpe65 mice (Rohrer et al., 2005).

IRBP is an abundant soluble protein component of the IPM that mediates various interactions between photoreceptors and RPE, including cell adhesion, phagocytosis, outer segment stability, and retinoids trafficking in the visual cycle (Hollyfield, 1999). IPM also contains numerous growth and neurotrophic factors that promote photoreceptor development and survival (Hage- 
man et al., 1991; Tombran-Tink et al., 1995). As reported in this study, the absence of IRBP in IPM resulted in significant changes of contents of TNF- $\alpha$, TNFR1, and RIP kinases in IPM and photoreceptors. Based on these results, we propose that IRBP is required for maintaining homeostasis of IPM, which is essential for photoreceptor development, survival, and function.

\section{References}

Ashkenazi A, Dixit VM (1998) Death receptors: signaling and modulation. Science 281:1305-1308. CrossRef Medline

Bazan NG, Reddy TS, Redmond TM, Wiggert B, Chader GJ (1985) Endogenous fatty acids are covalently and noncovalently bound to interphotoreceptor retinoid-binding protein in the monkey retina. J Biol Chem 260:13677-13680. Medline

Black RA, Rauch CT, Kozlosky CJ, Peschon JJ, Slack JL, Wolfson MF, Castner BJ, Stocking KL, Reddy P, Srinivasan S, Nelson N, Boiani N, Schooley KA, Gerhart M, Davis R, Fitzner JN, Johnson RS, Paxton RJ, March CJ, Cerretti DP (1997) A metalloproteinase disintegrin that releases tumournecrosis factor-alpha from cells. Nature 385:729-733. CrossRef Medline

Borst DE, Redmond TM, Elser JE, Gonda MA, Wiggert B, Chader GJ, Nickerson JM (1989) Interphotoreceptor retinoid-binding protein. Gene characterization, protein repeat structure, and its evolution. J Biol Chem 264:1115-1123. Medline

Bridges CD, Alvarez RA, Fong SL, Gonzalez-Fernandez F, Lam DM, Liou GI (1984) Visual cycle in the mammalian eye. Retinoid-binding proteins and the distribution of 11-cis retinoids. Vision Res 24:1581-1594. CrossRef Medline

Carlson A, Bok D (1992) Promotion of the release of 11-cis-retinal from cultured retinal pigment epithelium by interphotoreceptor retinoidbinding protein. Biochemistry 31:9056-9062. CrossRef Medline

Carter-Dawson L, Alvarez RA, Fong SL, Liou GI, Sperling HG, Bridges CD (1986) Rhodopsin, 11-cis vitamin A, and interstitial retinol-binding protein (IRBP) during retinal development in normal and rd mutant mice. Dev Biol 116:431-438. CrossRef Medline

Chautan M, Chazal G, Cecconi F, Gruss P, Golstein P (1999) Interdigital cell death can occur through a necrotic and caspase-independent pathway. Curr Biol 9:967-970. CrossRef Medline

Cho YS, Challa S, Moquin D, Genga R, Ray TD, Guildford M, Chan FK (2009) Phosphorylation-driven assembly of the RIP1-RIP3 complex regulates programmed necrosis and virus-induced inflammation. Cell 137: 1112-1123. CrossRef Medline

Cortina MS, Gordon WC, Lukiw WJ, Bazan NG (2003) Light-induced photoreceptor damage triggers DNA repair: differential fate of rods and cones. Adv Exp Med Biol 533:229-240. CrossRef Medline

Crouch RK, Hazard ES, Lind T, Wiggert B, Chader G, Corson DW (1992) Interphotoreceptor retinoid-binding protein and alpha-tocopherol preserve the isomeric and oxidation state of retinol. Photochem Photobiol 56:251-255. CrossRef Medline

Degterev A, Maki JL, Yuan J (2013) Activity and specificity of necrostatin-1, small-molecule inhibitor of RIP1 kinase. Cell Death Differ 20:366. CrossRef Medline

den Hollander AI, McGee TL, Ziviello C, Banfi S, Dryja TP, GonzalezFernandez F, Ghosh D, Berson EL (2009) A homozygous missense mutation in the IRBP gene (RBP3) associated with autosomal recessive retinitis pigmentosa. Invest Ophthalmol Vis Sci 50:1864-1872. Medline

Eisenfeld AJ, Bunt-Milam AH, Saari JC (1985) Immunocytochemical localization of interphotoreceptor retinoid-binding protein in developing normal and RCS rat retinas. Invest Ophthalmol Vis Sci 26:775-778. Medline

Fong SL, Bridges CD (1988) Internal quadruplication in the structure of human interstitial retinol-binding protein deduced from its cloned cDNA. J Biol Chem 263:15330-15334. Medline

Fontaine V, Mohand-Said S, Hanoteau N, Fuchs C, Pfizenmaier K, Eisel U (2002) Neurodegenerative and neuroprotective effects of tumor Necrosis factor (TNF) in retinal ischemia: opposite roles of TNF receptor 1 and TNF receptor 2. J Neurosci 22:RC216. Medline

Goll DE, Thompson VF, Li H, Wei W, Cong J (2003) The calpain system. Physiol Rev 83:731-801. Medline

Gonzalez-Fernandez F, Healy JI (1990) Early expression of the gene for interphotoreceptor retinol-binding protein during photoreceptor differentiation suggests a critical role for the interphotoreceptor matrix in retinal development. J Cell Biol 111:2775-2784. CrossRef Medline
Gonzalez-Fernandez F, Landers RA, Glazebrook PA, Fong SL, Liou GI, Lam DM, Bridges CD (1984) An extracellular retinol-binding glycoprotein in the eyes of mutant rats with retinal dystrophy: development, localization, and biosynthesis. J Cell Biol 99:2092-2098. CrossRef Medline

Gordon WC, Bazan NG (1993) Visualization of [3H]docosahexaenoic acid trafficking through photoreceptors and retinal pigment epithelium by electron microscopic autoradiography. Invest Ophthalmol Vis Sci 34: 2402-2411. Medline

Hageman GS, Kirchoff-Rempe MA, Lewis GP, Fisher SK, Anderson DH (1991) Sequestration of basic fibroblast growth factor in the primate retinal interphotoreceptor matrix. Proc Natl Acad Sci U S A 88:67066710. CrossRef Medline

He S, Wang L, Miao L, Wang T, Du F, Zhao L, Wang X (2009) Receptor interacting protein kinase-3 determines cellular necrotic response to TNF-alpha. Cell 137:1100-1111. CrossRef Medline

Hollyfield JG (1999) Hyaluronan and the functional organization of the interphotoreceptor matrix. Invest Ophthalmol Vis Sci 40:2767-2769. Medline

Jin M, Li S, Moghrabi WN, Sun H, Travis GH (2005) Rpe65 is the retinoid isomerase in bovine retinal pigment epithelium. Cell 122:449-459. CrossRef Medline

Jin M, Yuan Q, Li S, Travis GH (2007) Role of LRAT on the retinoid isomerase activity and membrane association of Rpe65. J Biol Chem 282:2091520924. CrossRef Medline

Jin M, Li S, Nusinowitz S, Lloyd M, Hu J, Radu RA, Bok D, Travis GH (2009) The role of interphotoreceptor retinoid-binding protein on the translocation of visual retinoids and function of cone photoreceptors. J Neurosci 29:1486-1495. CrossRef Medline

Kaneko Y, Rao NA (2012) Mitochondrial oxidative stress initiates visual loss in sympathetic ophthalmia. Jpn J Ophthalmol 56:191-197. CrossRef Medline

Kelly KJ, Sandoval RM, Dunn KW, Molitoris BA, Dagher PC (2003) A novel method to determine specificity and sensitivity of the TUNEL reaction in the quantitation of apoptosis. Am J Physiol Cell Physiol 284:C1309_ C1318. CrossRef Medline

Laabich A, Cooper NG (2000) Neuroprotective effect of AIP on N-methylD-aspartate-induced cell death in retinal neurons. Brain Res Mol Brain Res 85:32-40. CrossRef Medline

Lee EG, Boone DL, Chai S, Libby SL, Chien M, Lodolce JP, Ma A (2000) Failure to regulate TNF-induced NF-kappaB and cell death responses in A20-deficient mice. Science 289:2350-2354. CrossRef Medline

Li S, Lee J, Zhou Y, Gordon WC, Hill JM, Bazan NG, Miner JH, Jin M (2013a) Fatty acid transport protein 4 (FATP4) prevents light-induced degeneration of cone and rod photoreceptors by inhibiting RPE65 isomerase. J Neurosci 33:3178-3189. CrossRef Medline

Li S, Yang Z, Hu J, Gordon WC, Bazan NG, Haas AL, Bok D, Jin M (2013b) Secretory defect and cytotoxicity: the potential disease mechanisms for the retinitis pigmentosa (RP)-associated interphotoreceptor retinoidbinding protein (IRBP). J Biol Chem 288:11395-11406. CrossRef Medline

Liou GI, Bridges CD, Fong SL, Alvarez RA, Gonzalez-Fernandez F (1982) Vitamin A transport between retina and pigment epithelium-an interstitial protein carrying endogenous retinol (interstitial retinol-binding protein). Vision Res 22:1457-1467. CrossRef Medline

Liou GI, Wang M, Matragoon S (1994) Timing of interphotoreceptor retinoid-binding protein (IRBP) gene expression and hypomethylation in developing mouse retina. Dev Biol 161:345-356. CrossRef Medline

Liou GI, Fei Y, Peachey NS, Matragoon S, Wei S, Blaner WS, Wang Y, Liu C, Gottesman ME, Ripps H (1998) Early onset photoreceptor abnormalities induced by targeted disruption of the interphotoreceptor retinoidbinding protein gene. J Neurosci 18:4511-4520. Medline

Moiseyev G, Chen Y, Takahashi Y, Wu BX, Ma JX (2005) RPE65 is the isomerohydrolase in the retinoid visual cycle. Proc Natl Acad Sci U S A 102:12413-12418. CrossRef Medline

Montgomery SL, Bowers WJ (2012) Tumor necrosis factor-alpha and the roles it plays in homeostatic and degenerative processes within the central nervous system. J Neuroimmune Pharmacol 7:42-59. CrossRef Medline

Moss ML, Jin SL, Milla ME, Bickett DM, Burkhart W, Carter HL, Chen WJ, Clay WC, Didsbury JR, Hassler D, Hoffman CR, Kost TA, Lambert MH, Leesnitzer MA, McCauley P, McGeehan G, Mitchell J, Moyer M, Pahel G, Rocque W, et al. (1997) Cloning of a disintegrin metalloproteinase that 
processes precursor tumour-necrosis factor-alpha. Nature 385:733-736. CrossRef Medline

Murakami Y, Miller JW, Vavvas DG (2011) RIP kinase-mediated necrosis as an alternative mechanisms of photoreceptor death. Oncotarget 2:497509. Medline

Murakami Y, Matsumoto H, Roh M, Suzuki J, Hisatomi T, Ikeda Y, Miller JW, Vavvas DG (2012) Receptor interacting protein kinase mediates necrotic cone but not rod cell death in a mouse model of inherited degeneration. Proc Natl Acad Sci U S A 109:14598-14603. CrossRef Medline

Parker RO, Fan J, Nickerson JM, Liou GI, Crouch RK (2009) Normal cone function requires the interphotoreceptor retinoid binding protein. J Neurosci 29:4616-4621. CrossRef Medline

Parker R, Wang JS, Kefalov VJ, Crouch RK (2011) Interphotoreceptor retinoid-binding protein as the physiologically relevant carrier of 11-cisretinol in the cone visual cycle. J Neurosci 31:4714-4719. CrossRef Medline

Qtaishat NM, Wiggert B, Pepperberg DR (2005) Interphotoreceptor retinoid-binding protein (IRBP) promotes the release of all-trans retinol from the isolated retina following rhodopsin bleaching illumination. Exp Eye Res 81:455-463. CrossRef Medline

Redmond TM, Poliakov E, Yu S, Tsai JY, Lu Z, Gentleman S (2005) Mutation of key residues of RPE65 abolishes its enzymatic role as isomerohydrolase in the visual cycle. Proc Natl Acad Sci U S A 102:13658-13663. CrossRef Medline

Ripps H, Peachey NS, Xu X, Nozell SE, Smith SB, Liou GI (2000) The rhodopsin cycle is preserved in IRBP "knockout" mice despite abnormalities in retinal structure and function. Vis Neurosci 17:97-105. CrossRef Medline

Rohrer B, Lohr HR, Humphries P, Redmond TM, Seeliger MW, Crouch RK (2005) Cone opsin mislocalization in Rpe65-/- mice: a defect that can be corrected by 11-cis retinal. Invest Ophthalmol Vis Sci 46:3876-3882. CrossRef Medline

Rosenbaum DM, Degterev A, David J, Rosenbaum PS, Roth S, Grotta JC, Cuny GD, Yuan J, Savitz SI (2010) Necroptosis, a novel form of caspaseindependent cell death, contributes to neuronal damage in a retinal ischemia-reperfusion injury model. J Neurosci Res 88:1569-1576.

Sato K, Nakazawa M, Takeuchi K, Mizukoshi S, Ishiguro S (2010) S-opsin protein is incompletely modified during $\mathrm{N}$-glycan processing in Rpe65(-/-) mice. Exp Eye Res 91:54-62. CrossRef Medline

Sato K, Ozaki T, Ishiguro S, Nakazawa M (2012) M-opsin protein degradation is inhibited by MG-132 in Rpe $65^{-1-}$ retinal explant culture. Mol Vis 18:1516-1525. Medline

Smith SB, Hashimi W, Yielding KL (1988) Retinal degeneration in the mouse induced transplacentally by $\mathrm{N}$-methyl- $\mathrm{N}$-nitrosourea: effects of constant illumination or total darkness. Exp Eye Res 47:347-359. CrossRef Medline

Susin SA, Lorenzo HK, Zamzami N, Marzo I, Snow BE, Brothers GM, Mangion J, Jacotot E, Costantini P, Loeffler M, Larochette N, Goodlett DR, Aebersold R, Siderovski DP, Penninger JM, Kroemer G (1999) Molecular characterization of mitochondrial apoptosis-inducing factor. Nature 397:441-446. CrossRef Medline

Takahashi N, Duprez L, Grootjans S, Cauwels A, Nerinckx W, DuHadaway
JB, Goossens V, Roelandt R, Van Hauwermeiren F, Libert C, Declercq W, Callewaert N, Prendergast GC, Degterev A, Yuan J, Vandenabeele P (2012) Necrostatin-1 analogues: critical issues on the specificity, activity and in vivo use in experimental disease models. Cell Death Dis 3:e437. CrossRef Medline

Tang PH, Wheless L, Crouch RK (2011) Regeneration of photopigment is enhanced in mouse cone photoreceptors expressing RPE65 protein. J Neurosci 31:10403-10411. CrossRef Medline

Tanihara H, Yoshida M, Yoshimura N (1992) Tumor necrosis factor-alpha gene is expressed in stimulated retinal pigment epithelial cells in culture. Biochem Biophys Res Commun 187:1029-1034. CrossRef Medline

Tezel G (2008) TNF-alpha signaling in glaucomatous neurodegeneration. Prog Brain Res 173:409-421. CrossRef Medline

Tombran-Tink J, Shivaram SM, Chader GJ, Johnson LV, Bok D (1995) Expression, secretion, and age-related downregulation of pigment epithelium-derived factor, a serpin with neurotrophic activity. J Neurosci 15:4992-5003. Medline

Trichonas G, Murakami Y, Thanos A, Morizane Y, Kayama M, Debouck CM, Hisatomi T, Miller JW, Vavvas DG (2010) Receptor interacting protein kinases mediate retinal detachment-induced photoreceptor necrosis and compensate for inhibition of apoptosis. Proc Natl Acad Sci U S A 107: 21695-21700. CrossRef Medline

Van Hauwermeiren F, Vandenbroucke RE, Libert C (2011) Treatment of TNF mediated diseases by selective inhibition of soluble TNF or TNFR1. Cytokine Growth Factor Rev 22:311-319. CrossRef Medline

van Veen T, Katial A, Shinohara T, Barrett DJ, Wiggert B, Chader GJ, Nickerson JM (1986) Retinal photoreceptor neurons and pinealocytes accumulate mRNA for interphotoreceptor retinoid-binding protein (IRBP). FEBS Lett 208:133-137. CrossRef Medline

Waterhouse NJ, Finucane DM, Green DR, Elce JS, Kumar S, Alnemri ES, Litwack G, Khanna K, Lavin MF, Watters DJ (1998) Calpain activation is upstream of caspases in radiation-induced apoptosis. Cell Death Differ 5:1051-1061. CrossRef Medline

Wertz IE, O'Rourke KM, Zhou H, Eby M, Aravind L, Seshagiri S, Wu P, Wiesmann C, Baker R, Boone DL, Ma A, Koonin EV, Dixit VM (2004) De-ubiquitination and ubiquitin ligase domains of A20 downregulate NF-kappaB signalling. Nature 430:694-699. CrossRef Medline

Wisard J, Faulkner A, Chrenek MA, Waxweiler T, Waxweiler W, Donmoyer C, Liou GI, Craft CM, Schmid GF, Boatright JH, Pardue MT, Nickerson JM (2011) Exaggerated eye growth in IRBP-deficient mice in early development. Invest Ophthalmol Vis Sci 52:5804-5811. CrossRef Medline

Wu Q, Blakeley LR, Cornwall MC, Crouch RK, Wiggert BN, Koutalos Y (2007) Interphotoreceptor retinoid-binding protein is the physiologically relevant carrier that removes retinol from rod photoreceptor outer segments. Biochemistry 46:8669-8679. CrossRef Medline

Zhang DW, Shao J, Lin J, Zhang N, Lu BJ, Lin SC, Dong MQ, Han J (2009) RIP3, an energy metabolism regulator that switches TNF-induced cell death from apoptosis to necrosis. Science 325:332-336. CrossRef Medline

Znoiko SL, Rohrer B, Lu K, Lohr HR, Crouch RK, Ma JX (2005) Downregulation of cone-specific gene expression and degeneration of cone photoreceptors in the Rpe65-/- mouse at early ages. Invest Ophthalmol Vis Sci 46:1473-1479. CrossRef Medline 